\title{
THE PERFORMANCE OF THE SYSTEM FOR WATER RECOVERY FROM HUMIDITY CONDENSATE (SRV-K) AND THE SYSTEM FOR URINE FEED AND PRETREATMENT (SPK-U) ON RUSSIAN SEGMENT OF THE ISS (MISSIONS 1 THROUGH 37)
}

\author{
Professor Leonid Bobe ${ }^{1}$, Alexey Kochetkov ${ }^{2}$, Alexander Tsygankov ${ }^{3}$ \\ NIICHIMMASH, Moscow, Russia \\ Alexander Zeleznyakov ${ }^{4}$, Peter Andreychuk ${ }^{5}$ \\ RSC Energia, Korolev, Russia \\ Ju.E. Sinyak ${ }^{6}$ \\ IMBP RAN Moscow, Russia
}

\begin{abstract}
The paper summarizes the experience gained with the RS ISS water management system during the missions ISS-1 (since November 2, 2000) through ISS-37. The performance data of the system for water recovery from humidity condensate SRV-K and urine feed and pretreatment system SPK-U in the Russian orbital segment are presented. The key role of water recovery on board the ISS and the need to supplement the Russian segment water supply hardware with a system for water reclamation from urine SRV-U is shown. The prospects of regenerative water supply system development are considered
\end{abstract}

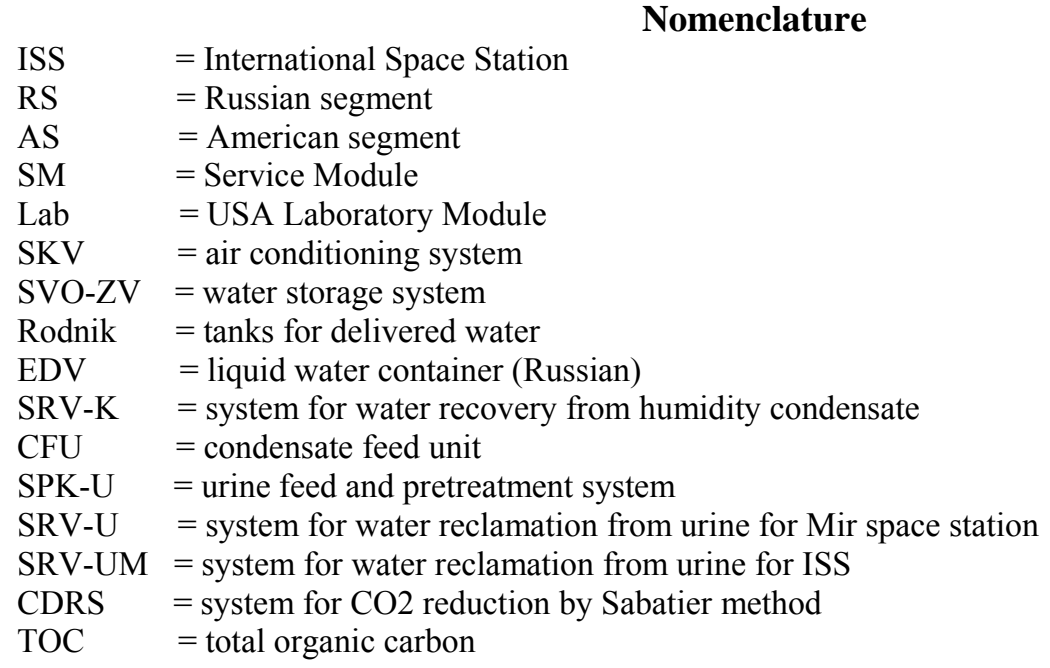

\section{Introduction}

With the International Space Station (ISS) earth orbital flight for twelve years wide experience in crew life support, in particular water supply has been obtained. The specific feature of the period under consideration in this paper is the water recovery system WRS put into operation in the US segment.

The construction and performance data of the water supply systems during the previous period of their functioning aboard the ISS have been reported at the ICES conferences [1].

\footnotetext{
${ }^{1}$ Head of laboratory, Life support division, 14 B.Novodmitrovskaya str., 125017, Moscow.

${ }^{2}$ Head of division, Life support division, 14 B.Novodmitrovskaya str., 125017, Moscow.

${ }^{3}$ The General Director of NIICHIMMASH, 14 B.Novodmitrovskaya str., 125017, Moscow.

${ }^{4}$ Head of Life support division RSC Energia , 4A Lenin str, 141070, Moscow.

${ }^{5}$ Head of sector, Life support department, 4A Lenin str,, 141070, Moscow.

${ }^{6}$ Head of department, Life support division, 76A Khoroshevskoe road,123007, Moscow.
} 
The water supply for the international space station (ISS) in years 2000 - 2009 has been provided by the Russian segment's systems. In November 2008 the US Lab module was outfitted with the systems for water recovery from humidity condensate and urine (WRS). Urine feed and pretreatment is accomplished in WRS by the system developed and built in Russia. The consumption of water recovered by the WRS was authorized in May 2009. In February 2010 the WRS system was moved to the new module Node-3 of the US segment.

With incorporation of the US WRS system the architecture and performance of the ISS water supply have changed. The paper reviews architecture and performance of the SM water supply before and after the introduction of the US water recovery systems in the module Node-3 and discusses the ways of improving water recovery systems for use in promising space missions.

The paper summarizes the experience gained with the ISS water management system during the missions ISS-1 (since November 2, 2000) through ISS-37. The performance data of the system for water recovery from humidity condensate SRV-K and urine feed and pretreatment system SPK-U in the Russian orbital segment are presented. The key role of water recovery on board the ISS and the need to supplement the Russian segment water supply hardware with a system for water reclamation from urine SRV-U is shown. The prospects of regenerative water supply system development are considered.

\section{ISS WATER MANAGEMENT DURING ISS 1 through ISS 17}

Fig. 1 is an ISS water supply schematic. Up to May 2009 potable water is supplied to the crew of the international space station by the Russian service module's systems, namely the system for water recovery from humidity condensate SRV-K and water supplies system SVO-ZV. The water sources are humidity condensate and water delivered from earth by Progress supply crafts or transferred from Shuttles. Since 2008 water was periodically delivered by the European ATV crafts. Humidity condensate is processed to potable water grade in the SRV-K system. The condensate is fed to the SRV-K from the service module's air conditioning system. The condensate in the U.S. Lab. module is collected in CWC tanks and transferred to the service module for processing in the SRV-K system. For this purpose the SRV-K system is incorporated with the condensate feed unit CFU (since April 2002). The water produced in Shuttle's fuel cells is processed and transferred to the station by the U.S. side. CWC tanks filled with potable water (with organic calcium and magnesium salts /formates/) and service water (with $0.5 \mathrm{mg} / \mathrm{L}$ silver ions) are transferred from the Lab module to the SM and are an integral part of the supplies system SVO-ZV. Progress supply crafts deliver specially processed tap water containing $0.5 \mathrm{mg} / \mathrm{L}$ of silver ions either in the Rodnik system's tanks or in EDV tanks.

The water is stored in the Rodnik system's tanks or in the system SVO-ZV. Potable water is consumed directly from SVO-ZV or the SRV-K system's potable water container is filled with it. Service water from CWC tanks is used as flush water in the urine feed and pretreatment system SPK-U. For oxygen generation by electrolysis either service water or water from the Rodnik system is used after being passed through water purifying facilities including a pumping unit, multifiltration bed (the same as in SRV-K), EDV for processed water and hoses.

Table 1 presents the station's water supply and consumption during ISS-1 through ISS-17 missions. The total water consumption on the station amounted to 25200 liters over the time period mentioned above including 11200 liters of water recovered from humidity condensate, i.e. $45 \%$ of the total amount of water used and $64 \%$ of the amount of potable water (25200) are provided by recovering water. In addition, 13190 liters of urine with flush water and pretreatment chemicals has been removed from the station. If that amount could have been processed, it would have resulted in 11870 liters of recovered water (with the coefficient of recovery equal to $90 \%$ ) and the amount of water delivered to the station would have been reduced by 10 times and accounted only for 1320 liters. Consequently, the incorporation of a system for water reclamation from urine as an integral part of the station's LSS is an urgent task. Table 2 gives the averaged water balance per cosmonaut per day over this time period. The total water consumption amounted to $3.65 \mathrm{~L} / \mathrm{man}$-day (with consideration for food ration water). During flight the station atmosphere was replenished by means of incoming spacecraft, therefore, the water required for oxygen generation by electrolysis was equal $0.65 \mathrm{~L} / \mathrm{man}$-day instead of theoretical value $1 \mathrm{~L} /$ man-day. With no atmosphere replenishment the water supplied for oxygen generation would be $1 \mathrm{~L} / \mathrm{man}$-day and the total daily water consumption would amount to 4 $\mathrm{L} / \mathrm{man}$-day. This data agrees with a theoretical value. 


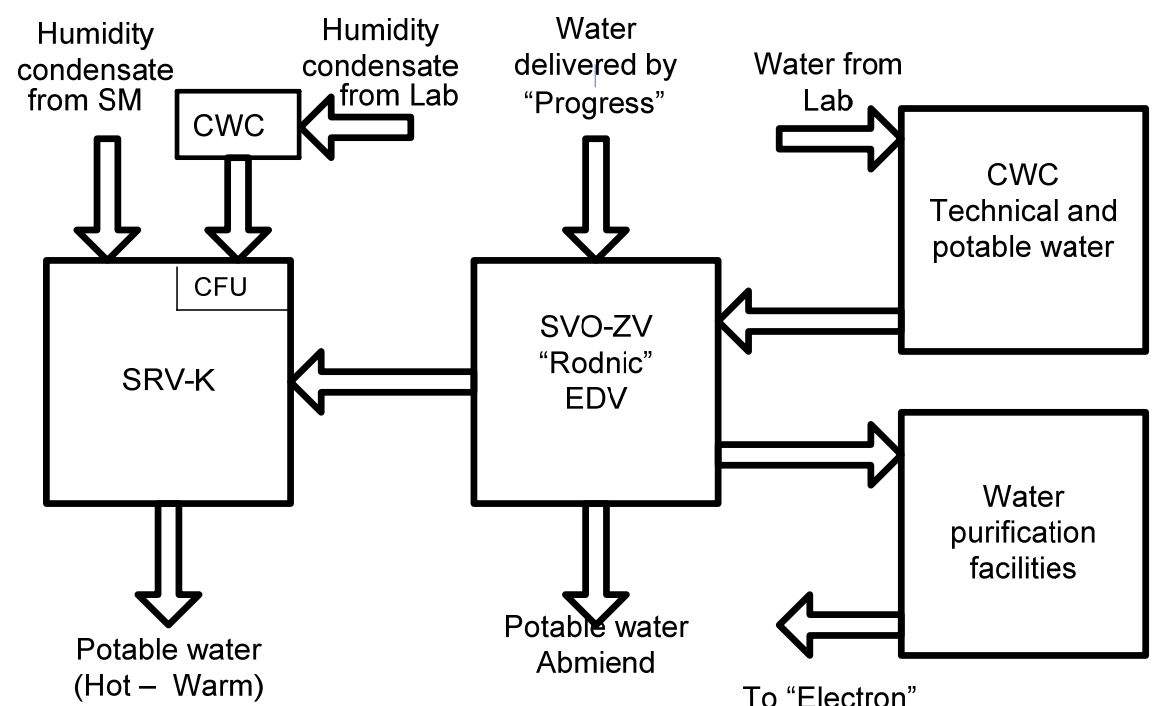

Fig.1. RS ISS water supply schematic

Table 1. ISS water supply and consumption during ISS-1 through ISS-17 missions (from 11/02/00 till 10/23/08; 2913 days, 8028 man-days)

\begin{tabular}{|c|c|c|c|c|c|}
\hline \multirow{2}{*}{$\begin{array}{l}\text { № } \\
\Pi / \Pi\end{array}$} & \multirow[t]{2}{*}{ Water source/ consumption } & \multicolumn{4}{|c|}{ Water consumption } \\
\hline & & $\begin{array}{l}\text { Per day, } \\
\text { L/day }\end{array}$ & $\begin{array}{l}\text { Total, } \\
\text { liter }\end{array}$ & $\begin{array}{l}\text { Part of } \\
\text { used } \\
\text { potable } \\
\text { water, \% }\end{array}$ & $\begin{array}{c}\text { Part of } \\
\text { used } \\
\text { total } \\
\text { water, \% }\end{array}$ \\
\hline 1 & $\begin{array}{l}\text { Potable water recovered from } \\
\text { humidity condensate }\end{array}$ & 3.85 & 11200 & 64 & 45 \\
\hline \multirow[t]{2}{*}{2} & Potable water from storage & & 6400 & 36 & \\
\hline & Potable water total & & 17600 & 100 & \\
\hline 3 & Service water from storage & & 7600 & & \\
\hline 4 & $\begin{array}{l}\text { Water from storage total } \\
\text { (potable and service water) }\end{array}$ & 4.80 & 14000 & & 55 \\
\hline 5 & $\begin{array}{l}\text { Total water consumption on } \\
\text { ISS ( } 3.15 \mathrm{~L} / \text { man-day) }\end{array}$ & 8.65 & 25200 & & 100 \\
\hline 6 & $\begin{array}{l}\text { Humidity condensate } \\
\text { collection: } \\
\text { - in service module SM } \\
\text { - in US Lab module } \\
\text { Total ( } 1.5 \mathrm{~L} / \text { man-day })\end{array}$ & 4.05 & $\begin{array}{c}8910 \\
842+2290 \\
12040\end{array}$ & & \\
\hline 7 & $\begin{array}{l}\text { Urine collection (without flush } \\
\text { water) }-1.33 \mathrm{~L} / \text { man-day }\end{array}$ & 3.67 & 10685 & & \\
\hline
\end{tabular}


Table 2. Averaged water supply and demand for one crewmember for ISS-1 through ISS-17

(for one astronaut per day)

\begin{tabular}{|c|c|c|c|}
\hline \multicolumn{2}{|c|}{ Demand for water, L/man-day } & \multicolumn{2}{|c|}{ Water supply, L/man-day } \\
\hline $\begin{array}{l}\text { Drinking and food preparation } \\
\text { Personal hygiene and plant } \\
\text { pouring } \\
\text { Water contained in food } \\
\text { Flush water } \\
\text { Oxygen generation } \\
\text { (the system for water electrolysis } \\
\text { did not work the whole period of } \\
\text { flight) }\end{array}$ & $\begin{array}{l}2.1 \\
0.1 \\
0.50 \\
0.30 \\
0.65(1.0)\end{array}$ & $\begin{array}{l}\text { Recovered by SRV-K from } \\
\text { humidity condensate (total amount } \\
\text { of condensate } 1.5 \mathrm{~L} \text { ) } \\
\text { Water contained in food } \\
\text { Water from supplies: } \\
\text { Drinking and food } \\
\text { Flush water } \\
\text { Oxygen generation }\end{array}$ & $\begin{array}{l}1.40 \\
0.50 \\
0.80 \\
0.30 \\
0.65(1.0)\end{array}$ \\
\hline Total & $3.65(4.0)$ & Total & $3.65(4.0)$ \\
\hline
\end{tabular}

Note: in brackets the settlement balance is specified at the charge of water on electrolysis $1 \mathrm{~L} /$ man-day.

\section{ISS WATER SUPPLY BY THE SERVICE MODULE SYSTEMS IN ISS 1 THROUGH ISS 37 MISSIONS}

The WRS located in the US segment has been tested since November 2008. This system is designed to recover water from humidity condensate and urine collected in US Lab module. As agreed, the SM systems shall work for two - three persons. As for the US Lab systems they shall work for the remaining crew members.

However during the tryout period and forced interruptions in the WRS performance the load on the SM systems was higher. In addition the water consumption provided by the WRS began only in May 2009.

Table 3 presents the water supply parameters and SM water consumption in ISS 18 through ISS 37 missions from 10/24/08 till 02/01/14. During that period of time the potable water consumption amounted to 10345 liters including 4955 liters of water recovered from humidity condensate i.e. $48 \%$ of potable water consumed and $31 \%$ of the total water consumption (15930) were provided by recovering water. The specific values per man/day remained approximately the same they were before.

Table 4 presents the water supply parameters and SM water consumption in ISS 1 through ISS 34 missions from $11 / 02 / 00$ till $02 / 01 / 14$. During that period of time the potable water consumption amounted to 27495 liters including 16155 liters of water recovered from humidity condensate i.e. $59 \%$ of potable water consumed and $39 \%$ of the total water consumption (as 41130) were provided by recovering water. The specific values per man/day remained approximately the same they were before.

\section{WATER RECOVERY FROM HUMIDITY CONDENSATE. SRV-K SYSTEM.}

The method of water recovery is based on multi-stage sorption-catalytic purification of condensate followed by water mineralization and decontamination. Water is decontaminated with dissolved ionic silver and pasteurized. The condensate is transported to the SRV-K system as a water-air mixture (through a pipe). This requires the incorporation of a separator operated in the system under microgravity conditions. After separation the liquid is transferred by pumps and all the processes are conducted in a liquid phase. Fig. 2 presents a schematic of the SRV-K system installed in the service module (SM) of the international space station (ISS).

The SRV-K system comprises three subsystems:

- filtration, preliminary purification and separation;

- purification and mineralizing;

- potable water storage, heating and dispensing. 
Table 3. ISS SM water supply and consumption during ISS-18 through ISS-37 missions (from 10/24/08 till 02/01/14; 1926 days )

\begin{tabular}{|c|c|c|c|c|c|}
\hline \multirow{2}{*}{$\begin{array}{l}\text { № } \\
\Pi / \Pi\end{array}$} & \multirow[t]{2}{*}{ Water source/ consumption } & \multicolumn{4}{|c|}{ Water consumption } \\
\hline & & $\begin{array}{c}\text { Per day, } \\
\text { L/day }\end{array}$ & $\begin{array}{c}\text { Total, } \\
\text { liter }\end{array}$ & $\begin{array}{c}\text { Part of } \\
\text { used potable } \\
\text { water, } \%\end{array}$ & $\begin{array}{c}\text { Part of } \\
\text { used total } \\
\text { water, } \%\end{array}$ \\
\hline 1 & $\begin{array}{l}\text { Potable water recovered from humidity } \\
\text { condensate }\end{array}$ & 2.57 & 4955 & 48 & 31 \\
\hline \multirow[t]{2}{*}{2} & Potable water from storage & & 5390 & 52 & \\
\hline & Potable water total & & 10345 & 100 & \\
\hline 3 & Service water from storage & & 5585 & & \\
\hline 4 & $\begin{array}{l}\text { Water from storage total } \\
\text { (potable and service) }\end{array}$ & 5.7 & 10975 & & 69 \\
\hline 5 & $\begin{array}{l}\text { Total water consumption on SM ISS } \\
\text { (3.2 L/man-day) }\end{array}$ & 8.3 & 15930 & & 100 \\
\hline
\end{tabular}

Table 4. ISS SM water supply and consumption during ISS-1 through ISS-37 missions (from 11/02/00 till 02/01/14; 4839 days)

\begin{tabular}{|c|c|c|c|c|c|}
\hline \multirow[t]{2}{*}{ № ח/п } & \multirow[t]{2}{*}{ Water source/ consumption } & \multicolumn{4}{|c|}{ Water consumption } \\
\hline & & $\begin{array}{c}\text { Per day, } \\
\text { L/day }\end{array}$ & $\begin{array}{l}\text { Total, } \\
\text { liter }\end{array}$ & $\begin{array}{c}\text { Part of } \\
\text { used total } \\
\text { water, \% }\end{array}$ & $\begin{array}{c}\text { Part of } \\
\text { used total } \\
\text { water, \% }\end{array}$ \\
\hline 1 & $\begin{array}{l}\text { Potable water recovered from } \\
\text { humidity condensate }\end{array}$ & 3.4 & 16155 & 59 & 39 \\
\hline \multirow[t]{2}{*}{2} & Potable water from storage & & 11790 & 41 & \\
\hline & Potable water total & & 27945 & 100 & \\
\hline 3 & Service water from storage & & 13185 & & \\
\hline 4 & $\begin{array}{l}\text { Water from storage total } \\
\text { (potable and service) }\end{array}$ & 5.2 & 24975 & & 61 \\
\hline 5 & $\begin{array}{l}\text { Total water consumption on } \\
\text { SM ISS ( } 3.16 \mathrm{~L} / \text { man-day) }\end{array}$ & 8.5 & 41130 & & 100 \\
\hline 6 & $\begin{array}{l}\text { Humidity condensate } \\
\text { collection }-1.5 \mathrm{~L} / \mathrm{man} \text {-day } \\
\text { Urine collection (without } \\
\text { flush water) }-1.33 \mathrm{~L} / \mathrm{man} \text { - } \\
\text { day }\end{array}$ & 3.6 & $\begin{array}{r}25240 \\
17403\end{array}$ & & \\
\hline
\end{tabular}


The humidity condensate transported by air is passed through a particulate filter and enters a filter/reactor where condensate organic contaminants are oxidized catalytically (about by 80-90\%) with the oxygen of the carrier air. The process occurs at the station atmospheric pressure and temperature. The condensate is separated from the transporting air in a static separator. Separation is accomplished with the use of tubes with capillary/porous walls.

The condensate is passed through a multifiltration bed unit to remove organic and inorganic contaminants by sorption/catalytic and ion-exchange methods. The multifiltration bed unit comprises catalysts, sorbents and ionexchange resins. After quality control by conductivity measurement, purified water enters a mineralizing unit to be mineralized (by direct contact with a granular mineralizer bed) with inorganic salts and decontaminated with ionic silver. Mineralized water is collected in a bladder tank (a potable water container). Water is pasteurized in the heater before consumption.

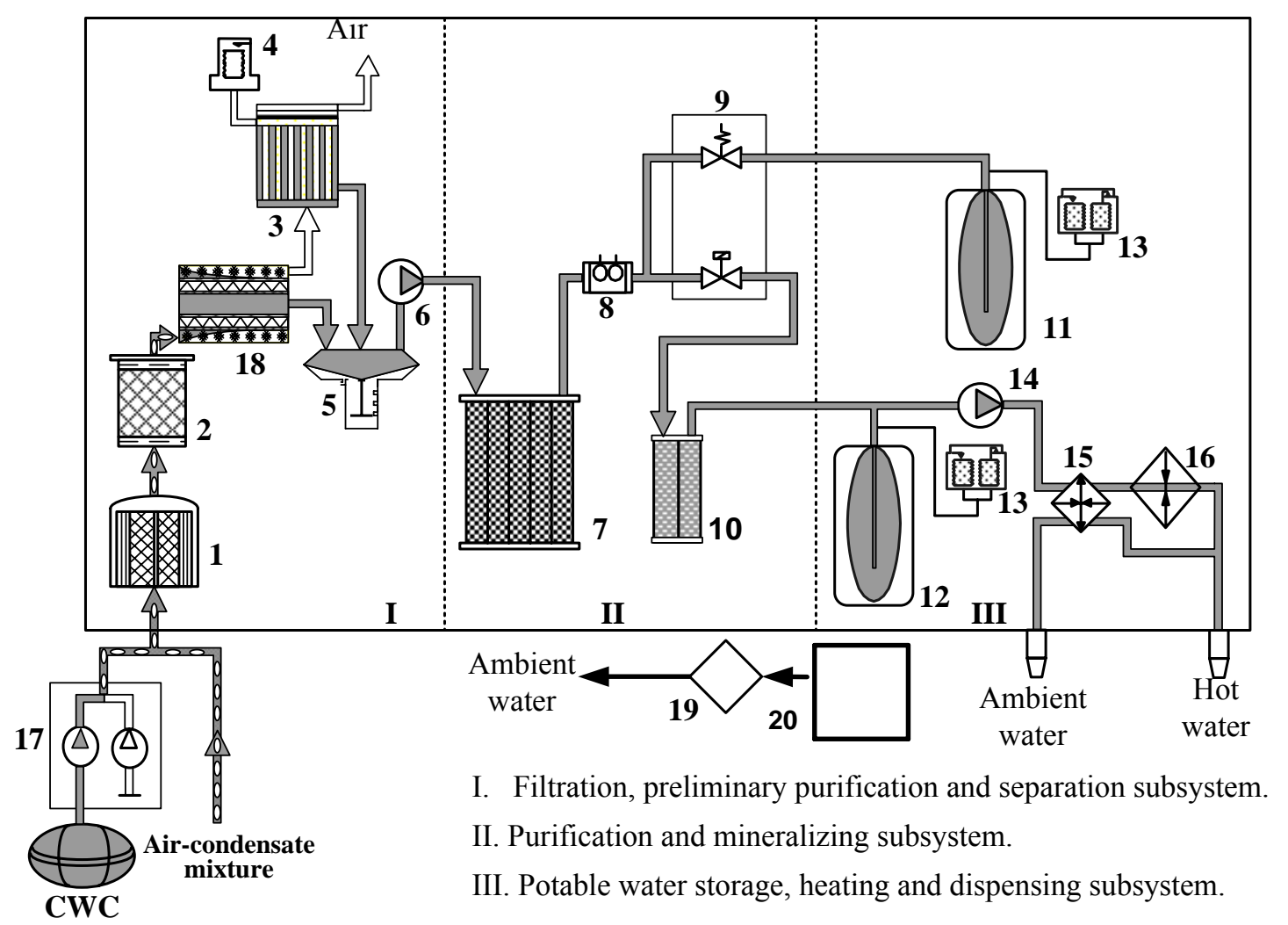

1. Gas/liquid mixture filter. 2. Filter/reactor. 3. Separator. 4. Separator life sensor. 5. Condensate receiver. 6. Condensate pump. 7. Multifiltration unit. 8. Water quality sensor. 9. Valve unit. 10. Mineralizing. 11. Service water tank. 12. Potable water tank. 13. Tank empty/full indicator. 14. Recovered water feed pump. 15. Heat exchanger. 16. Heater. 17. Condensate feed unit. 18. Membrane separator. 19. Microbial filter. 20. EDV water tank. CWC - tank for condensate collection from US Lab module.

Fig. 2. ISS SM system for water recovery from humidity condensate SRV-K.

Multiple sample analysis data of recovered potable water confirmed its conformity with the specifications. The data on microbiological analyses of potable water from the SRV-K performed by U.S. astronauts on board the station also confirm its conformity with the ISS specifications [5]. The condensate and recovered potable water sample analyses from the ISS are presented in Table 5 (about 60 samples of each kind of water). Apparently, despite the raised maintenance of impurity in a condensate, the system provides its clearing from organic and inorganic impurities.

There are two new units in the SRV-K system: membrane separator and microbial filter. Using of the membrane separator increases the separation units (positions 3 and 18) life time by 10 times, using of the microbial filter allows to consumption of ambient water from water tanks. 
The power consumption and mass requirements of the SRV-K system on the ISS are given in Table 6.

The system features very low power consumption and mass requirements. The average daily power consumption for separation and recovery is less than $0.4 \mathrm{~W}$ per 3 cosmonauts. The mass requirements are 14 times lower than the mass requirements in case of water delivery. For the period considered (from Nov.02, 2000 till February 01, 2014) the SRV-K system processed 27945 liters of potable water from humidity condensate and other water to potable grade.

The quality of water conformed to the specifications for ISS. The specific mass of system expendable components and specific energy for a liter of water recovered was $0.09 \mathrm{~kg} / \mathrm{L} \mathrm{of} \mathrm{H}_{2} \mathrm{O}$ and $2 \mathrm{~W}-\mathrm{hr} / \mathrm{L}$ of $\mathrm{H}_{2} \mathrm{O}$ respectively. Daily average power consumption for a three-person crew was $30 \mathrm{~W}$.

The amount of water recovered for the period considered was $59 \%$ of potable water and $39 \%$ of total water consumption.

Table 5. Condensate and recovered water sample analysis data (from Nov. 2, 2000 till February 1, 2014)

\begin{tabular}{|c|c|c|c|c|c|c|c|c|c|c|c|c|}
\hline \multirow[b]{3}{*}{$\begin{array}{c}\text { Condensate } \\
\text { source }\end{array}$} & \multicolumn{12}{|c|}{ Basic contaminant concentration, $\mathrm{mg} / \mathrm{L}$} \\
\hline & \multicolumn{6}{|c|}{ Condensate going into SRV-K } & \multicolumn{6}{|c|}{ Recovered water } \\
\hline & 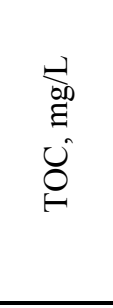 & 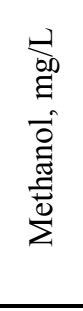 & 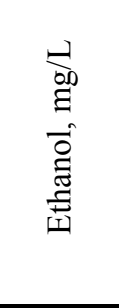 & 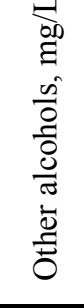 & 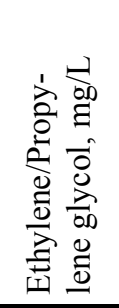 & 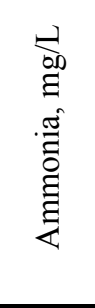 & 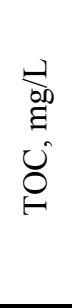 & 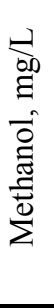 & 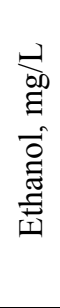 & 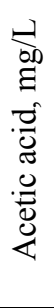 & 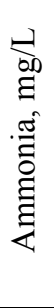 & 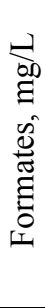 \\
\hline Norm for ISS & 100 & 10 & 60 & 25 & 20 & 45 & 22 & 9 & 10 & - & 2 & - \\
\hline $\begin{array}{l}\text { SM } \\
\text { condensate }\end{array}$ & $60-160$ & $6-10$ & $40-105$ & $3-12$ & $3-15$ & $10-20$ & \multirow[t]{2}{*}{$\begin{array}{c}0.1- \\
2\end{array}$} & \multirow[t]{2}{*}{0} & \multirow[t]{2}{*}{$0-4$} & \multirow[t]{2}{*}{0} & \multirow[t]{2}{*}{0} & \multirow[t]{2}{*}{0} \\
\hline $\begin{array}{l}\text { US LAB } \\
\text { condensate }\end{array}$ & $\begin{array}{l}115- \\
350 \\
\end{array}$ & $3-6$ & $30-125$ & $2-44$ & $30-135$ & $30-88$ & & & & & & \\
\hline
\end{tabular}

Table 6. Power consumption and mass requirements of the water recovery system SRV-K (from November 2, 2000 till February 1, 2014)

\begin{tabular}{|c|c|}
\hline Mass of the initially installed system & $115 \mathrm{~kg}$ \\
\hline $\begin{array}{l}\text { Average daily power consumption } \\
\text { for } 3 \text { person crew } \\
\qquad \begin{aligned} * & \text { for feed and recovery } \\
* & \text { for feed, recovery and heating }\end{aligned}\end{array}$ & $\begin{array}{l}0.4 \mathrm{~W} \\
30 \mathrm{~W} \\
\end{array}$ \\
\hline Specific energy for feed and recovery & $2 \mathrm{~W}-\mathrm{hr} / \mathrm{L} \mathrm{H}_{2} \mathrm{O}$ \\
\hline $\begin{array}{l}\text { Mass of the hardware replaced during the flight (ORU) } \\
\qquad \begin{array}{l}* \text { total } \\
* \text { specific }\end{array}\end{array}$ & $\begin{array}{c}1390 \mathrm{~kg} \\
0.086 \mathrm{~kg} / \mathrm{L} \mathrm{H}_{2} \mathrm{O}\end{array}$ \\
\hline $\begin{array}{l}\text { Amount of water recovered: } \\
\text { - from humidity condensate } \\
\text { - from humidity condensate and other water }\end{array}$ & $\begin{array}{l}16155 \mathrm{~L} \\
27945 \mathrm{~L} \\
\end{array}$ \\
\hline $\begin{array}{l}\text { Savings in mass of water to be delivered in the absence of } \\
\text { water recovering (including the mass of tanks } 0.25 \mathrm{~kg} / \mathrm{L} \\
\text { minus mass of the replaced hardware delivery } 1390 \mathrm{~kg} \text { ) }\end{array}$ & $18800 \mathrm{~kg}$ \\
\hline
\end{tabular}




\section{URINE COLLECTION}

The service module is outfitted with the urine feed and pretreatment system with its schematic presented in fig.3. Urine fed to the urinal is transported by air through the rotary separator. With each portion of urine a metered amount of pretreatment chemicals and flush water is injected in a urine/air mixture. Separated and pretreated urine is passed over to the EDV tank, its filling being indicated by the pressure transmitter. The air from the separator leaves through the backup separator, liquid droplet carryover sensor, fan and air filter.

The system uses pretreatment chemicals based on sulfuric acid and chromium oxide. The system performance data are given in Table 7. The subsystem features the low specific mass and power consumption required for feed and separation of a liter of urine equal to $0.08 \mathrm{~kg}$ and $30 \mathrm{~W}-\mathrm{hr}$ respectively. The crew repeatedly spoke favorably of easy use of the system. It should be noted that an analogy system was installed in November 2008 in US Segment for urine processing assembly (UPA) and it has been used since February 2009.

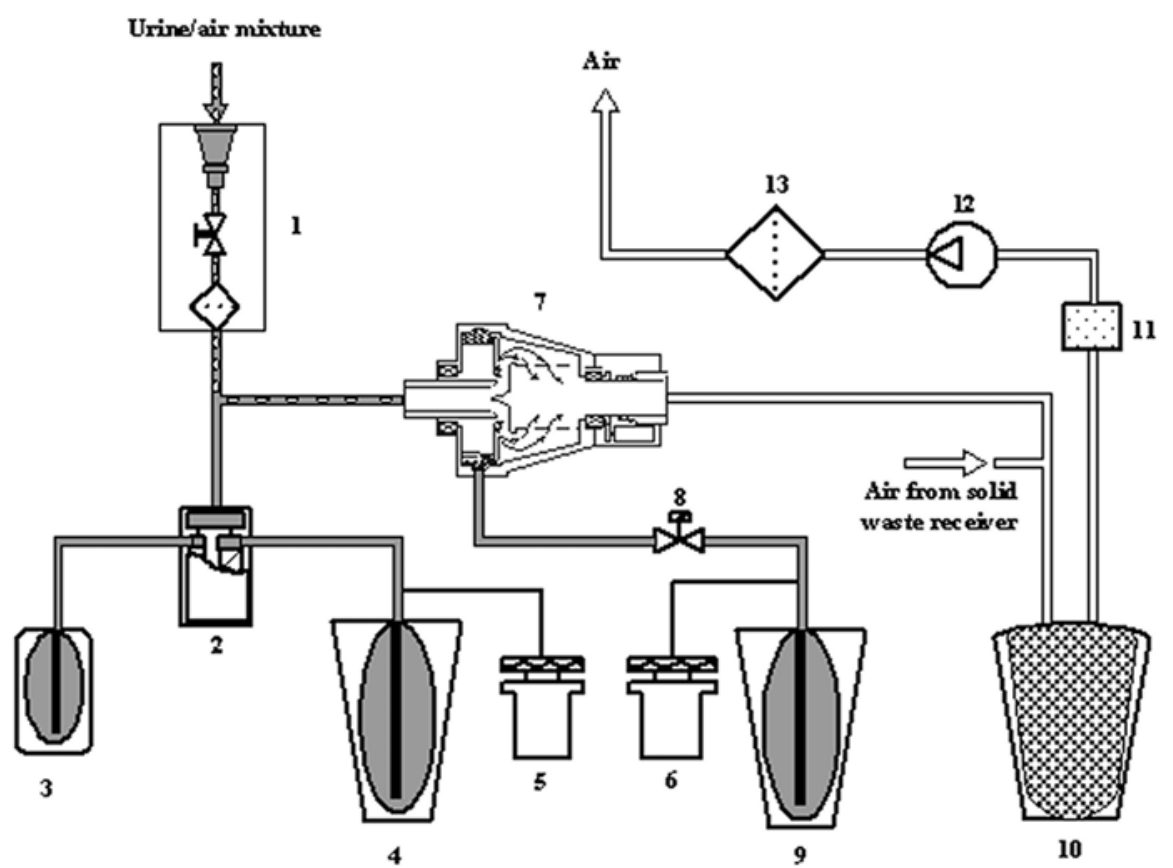

1. Urinal. 2. Pretreatment chemicals and flush water metering device. 3. Pretreatment chemicals tank. 4. Flush water tank. 5,6. Tank empty/full indicator. 7. Rotary separator. 8. Valve. 9. Urine feed tank (EDV). 10. Back-up static separator. 11. Liquid droplet carryover sensor. 12. Fan. 13. Air filter.

Fig. 3. Urine feed and pretreatment system SPK-U

Table 7. SPK-U system operation on ISS SM from November 2, 2000 till February 1, 2013

\begin{tabular}{||l|c||}
\hline \hline Operation period & 4839 days \\
\hline Total amount of uses & $82697(17$ uses/day $)$ \\
\hline Total amount of urine feed & $17403 \mathrm{~L}$ \\
\hline Daily amount of urine feed & $1.34 \mathrm{~L} / \mathrm{man}$-day \\
\hline Total amount of urine with flush water and pretreatment & $21724 \mathrm{~L}$ \\
\hline Power consumption for urine feed & $120 \mathrm{~W}$ \\
\hline Average daily power consumption for 3-person crew & $5 \mathrm{~W}$ \\
\hline Specific energy consumption for 1 L of urine & $30 \mathrm{~W}-\mathrm{hr} / \mathrm{L}$ of urine \\
\hline Mass of hardware replaced during the flight & $1390 \mathrm{~kg}$ \\
\hline Specific mass of replaceable hardware for 1 L of urine & $0.08 \mathrm{~kg} /$ liter of urine \\
\hline
\end{tabular}




\section{RECOVERED WATER SUPPLY SYSTEM DEVELOPMENT PROSPECTS}

In the future a new module is supposed to be incorporated in the Russian segment of the station. This module will be outfitted with an updated system for water reclamation from urine SRV-UM. Unlike the system for water reclamation from urine SRV-U installed on space station Mir the SRV-UM system features vacuum distillation with a multistage rotary vacuum distiller and a thermoelectric heat pump [2,3,4]. At the processing rate of distillation of $2.5 \mathrm{~L} / \mathrm{hr}$ energy consumption (including power of distiller engine) will be not more than $150 \mathrm{~W}$-hr per 1 liter of processed condensate. The water efficiency of water recovery from urine is $90 \%$.

A promising ISS Russian orbital Segment life support schematic is presented in fig.4. The SRV-UM and $\mathrm{CO}_{2}$ reduction system (Sabatier reactor) are included in LSS.

Estimated water supply and demand for one crewmember after incorporating the SRV-UM system in LSS is presented in Table 8. As seen from the table the amount of water from supplies is reduced from $1.9 \mathrm{~L} / \mathrm{man}$-day (column1) to $0.46 \mathrm{~L} /$ man-day (column 2). If a system for $\mathrm{CO}_{2}$ reduction CDRS (water production rate is 0.45 $\mathrm{L} /$ man-day accordance with the hydrogen balance) is included in LSS the water balance will be practically provided for by the systems: SRV-K, SRV-UM, CDRS and water delivery will be minimized (column 3)

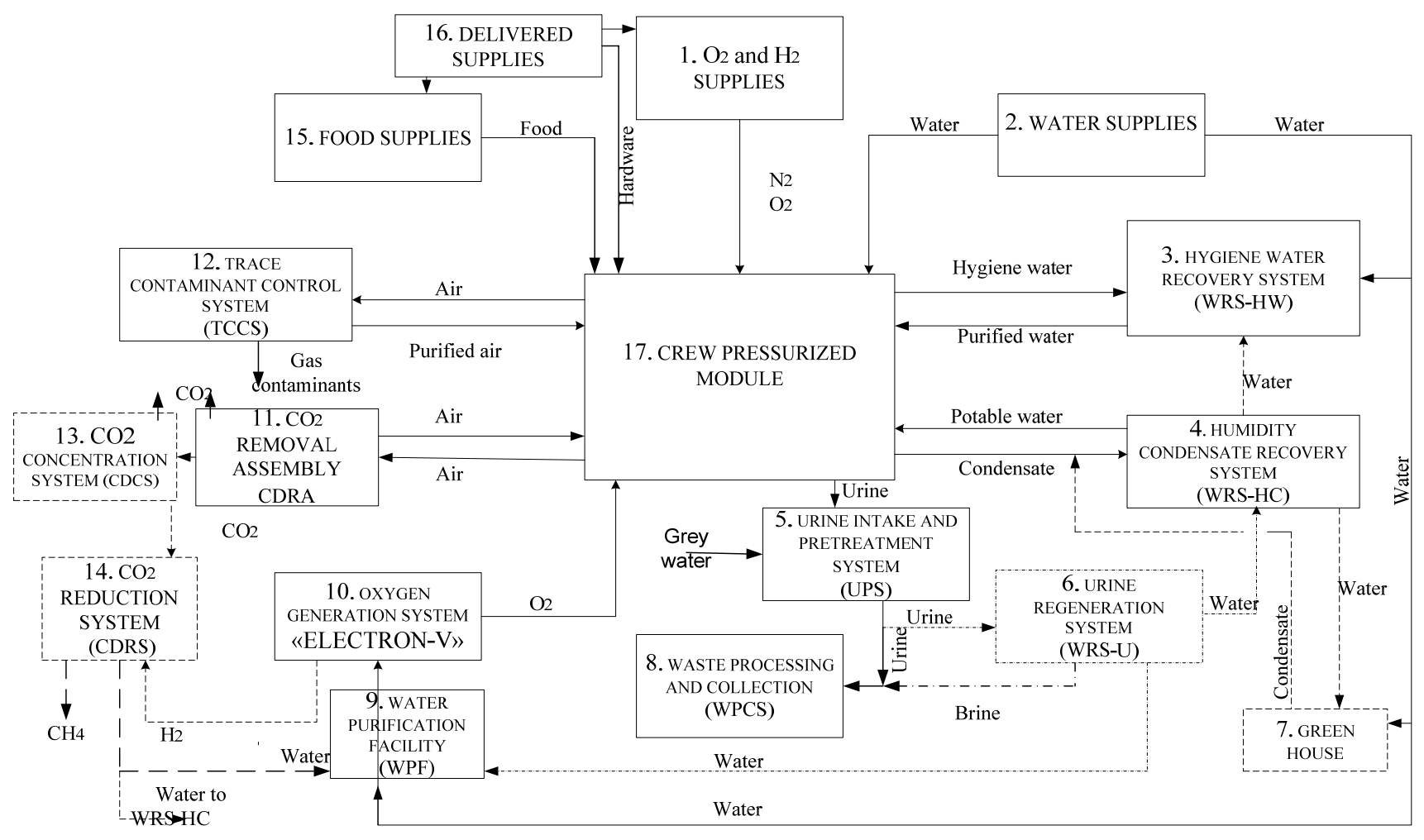

Fig.4. Promising ISS RS life support schematic 
Table 8. Water supply and demand for one crewmember with water recovery in SRV-K, SRV-UM, CDRS.

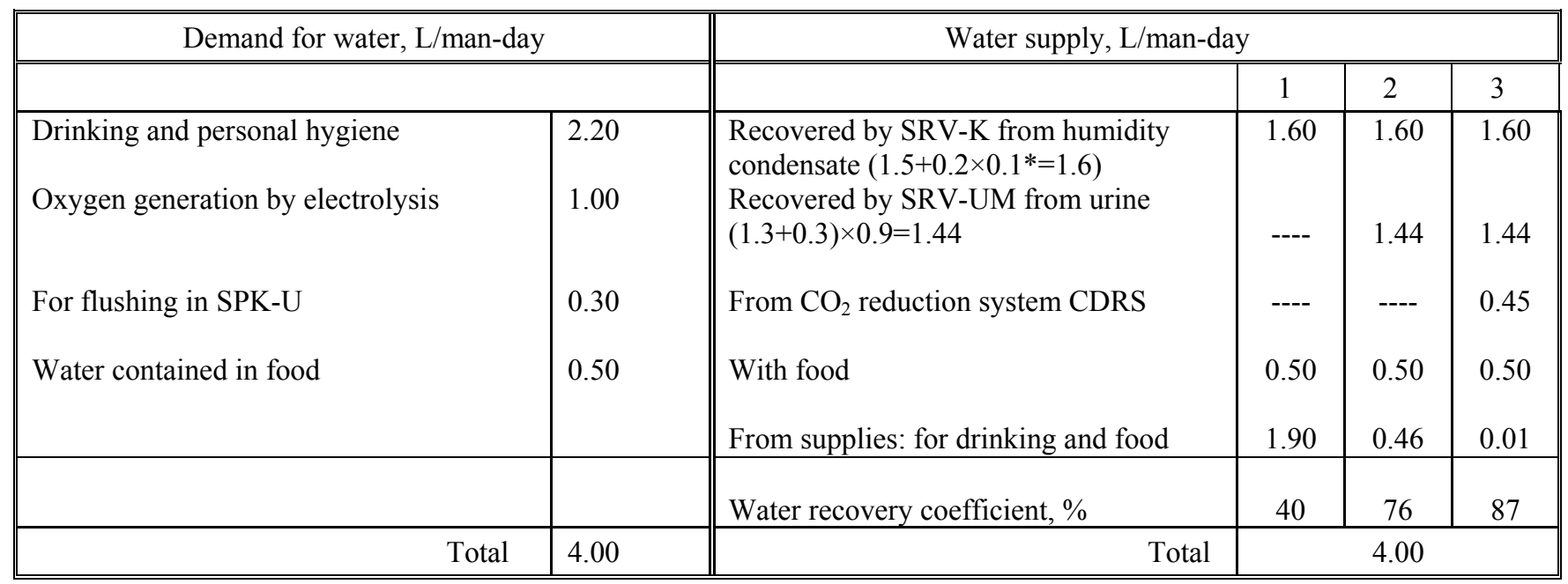

* Drying of hygiene towel.

$1,2,3$ - the options of recovery systems integration.

\section{CONCLUSION}

1. From November 2, 2000 till February 1, 2014 the SRV-K system provided 16155 liters of water recovered from humidity condensate. It amounts to $59 \%$ of crew needs for potable water and $39 \%$ of the total demand for water on board the station. The quality of recovered water fully complies with the specifications made for ISS SM.

2. Specific mass expendables for water recovery from humidity condensate were $0.086 \mathrm{~kg}$ per liter of recovered water. Savings in water mass delivery was $18800 \mathrm{~kg}$.

3. From November 2, 2000 till February 1, 2014 the SPK-U system collected 17403 liters of crew urine, with its pretreatment and storage. Average daily amount of urine feed is $1.34 \mathrm{~L} / \mathrm{man}$-day. Specific mass expendables for urine feed and pretreatment were $0.08 \mathrm{~kg}$ per liter of urine.

4. If the module with the planned installation of the SRV-UM system is incorporated in the station, the design requirement for water delivery will be reduced from $1.9 \mathrm{~L} /$ man-day to $0.46 \mathrm{~L} /$ man-day.

If the carbon dioxide reduction system is integrated in the LSS, the design requirement for water mass delivery will be minimized.

\section{REFERENCES}

1. SAE Technical paper series: 2001-01-2355, 2002-01-2358, 2003-01-2622, 2004-01-2489, 2005-01-2806, 200601-2269, 2007-01-3174, 2008-01-2191, 2009-01-2485, AIAA 2010-6268, AIAA 2011-5073, AIAA-2012-3400.

2. N.M.Samsonov, L.S.Bobe, V.M.Novikov, N.N.Protasov etc.

A Regenerative Water Supply System for the ISS Russion Segment.

$29^{\text {th }}$ ICES, July 12-15, 1999, Denver, USA, SAE Technical paper series 1999-01-1951.

3. N.M.Samsonov, L.S.Bobe, V.M.Novikov, N.S.Farafonov, Ju.I.Grigoriev, S.Ju.Romanov, N.N.Protasov, Ju.E.Sinyak, V.M.Baranov

Experience in Development and Operation of a Regenerative System for Water Supply on Mir Space Station. $30^{\text {th }}$ ICES, July 10-13, 2000, Toulouse, France, SAE Technical paper series 2000-01-2517. 
4. N.M.Samsonov, L.S.Bobe, V.M.Novikov, N.S. Farafonov, B.Ja. Pinsky, V.V. Rakov, V.G. Rifert, N.N. Protasov etc.

Updated Systems for Water Recovery from Humidity Condensate and Urine for the International Space Station. $27^{\text {th }}$ ICES, July 14-17, 1997, Lake Tahoe, Nevada, USA. SAE Technical paper series 972559.

5. Debra K. Plumlee, Paul D. Mudgett, John R. Shultz ISS Potable Water Sampling and Chemical Analysis: Expedition 4-6.

$23^{\text {rd }}$ ICES, July 7-10, 2003, Vancouver, Canada. SAE Technical paper series 2003-01-2401. 